\title{
Overweight and Obesity among Russian, Somali, and Kurdish Origin Populations in Finland
}

\author{
NATALIA SKOGBERG ${ }^{1}$ \\ ADAM ADAM $^{1}$ \\ TARJA KINNUNEN ${ }^{2}$ \\ EERO LILJA ${ }^{1}$ \\ ANU E. CASTANEDA ${ }^{1,3}$
}

1 National Institute for Health and Welfare (THL), Helsinki, Finland

2 University of Tampere, Finland

3 University of Helsinki, Finland

\section{Abstract}

Previous studies have shown the prevalence of overweight and obesity to be higher in foreign-born populations than their native counterparts. This study aimed at assessing the prevalence of overweight and obesity in Russian, Somali and Kurdish origin populations in Finland in comparison with the general population, and determining which background factors are associated with overweight and obesity. Data from the Finnish Migrant Health and Wellbeing Study (Maamu) were used. Prevalence of overweight and obesity was as high as $73 \%$ in Somali and $65 \%$ in Kurdish origin women. In contrast, Somali origin men had a significantly lower prevalence of overweight and obesity than men in the general population. Health promotion measures should aim at decreasing the prevalence of overweight and obesity particularly among Somali and Kurdish origin women. Foreign-born people need to be taken into account when planning and implementing national obesity prevention programs.

Keywords: Overweight; Obesity; Migrant; Population-based study; Survey; Maamu 


\section{Introduction}

The alarming increase in the prevalence of overweight and obesity in the last decades has made them a global public health problem that threatens peoples' health and wellbeing universally (Caballero 2007; Flegal et al 2012; Groves 2006). Overweight and obesity are associated with older age, female sex, lower socioeconomic status, poor diet and low levels of physical activity (Everson et al. 2002; Lahti-Koski et al. 2000; WHO 2015). Likewise, parity has been repeatedly demonstrated to be associated with overweight and obesity among women (Davis et al. 2009; Kim, Stein and Martorell 2007).

Several studies have demonstrated that the prevalence of overweight and obesity tends to be higher among migrant origin populations than the general population in the country of migration (Gele and Mbalilaki 2013; Oza-Frank and Cunningham 2010; Sussner et al. 2008). Previous studies also indicate that prevalence of overweight and obesity among migrants increases with longer length of stay in the host country (Ro and Bostean 2015; Singh et al. 2011).

Some studies indicate that migrants' high obesity rates can be attributed to lifestyle and environmental changes (Delavari et al. 2013; Franzen and Smith 2009). A change from a traditional diet to a more industrial one, accompanied with decreased energy expenditure due to the urbanization, have been suggested to be the contributing factors to the observed high prevalence rates of overweight and obesity among migrant origin populations (Toselli et al. 2014). Hence, some studies emphasise that acculturation plays a key role in explaining why migrants living in high-income countries have a high prevalence of overweight and obesity. For example, Toselli et al. noted that migrants' disease patterns change rapidly after migration and become similar to the disease pattern of the inhabitants of the host country.

A recent health examination survey in Finland, FINRISK 2012, illustrated that the prevalence of overweight and obesity in Finland has increased among men since the 1970s and among women since the 1980s (Männistö et al. 2015). Prevalence of overweight or obesity was $66 \%$ in men and $46 \%$ in women. Among men and women in Finland, one in five was obese. High prevalence of obesity among Somali and Kurdish origin women aged 30 years and older living in Finland has been previously reported (Skogberg et al. 2016). Despite these findings, overweight and obesity among foreign origin populations in Finland has not yet been studied extensively.

The foreign origin population in Finland is increasing and it is projected that migrants will constitute $10 \%$ of the population within the next few years (Ministry of the Interior 2016). As the share of foreign origin population is growing, there is an enormous need to study the health, including overweight and obesity, among migrants residing in Finland. Despite extensive information on the high prevalence rates of overweight and obesity among some migrant origin population on an international level, there is insufficient information on factors associated with overweight and obesity among different migrant groups living in the Nordic countries. 
Therefore, we firstly aim to compare the prevalence of overweight and obesity in adult foreign-born populations of Russian, Somali and Kurdish origin in Finland to that in the general Finnish population. Secondly, we aim to determine which background factors (age, gender, education, employment status, years lived in Finland, physical activity, diet, and parity) are associated with overweight and obesity in migrants of Russian, Somali and Kurdish origin and the Finnish general population. Findings of this study will facilitate planning of health interventions and obesity prevention programs that are targeted to meet the needs of these migrant origin populations in Finland.

\section{Methods}

\section{Design and study populations}

The present study uses data from the cross-sectional Migrant Health and Wellbeing Study (Maamu), conducted by the National Institute for Health and Welfare (THL) in Finland between 2010 and 2012. Detailed information about the methods of the Maamu Study can be found elsewhere (Castaneda et al. submitted for publication). Briefly, a random sample of 3,000 persons of Russian, Somali and Kurdish origin (1,000 for each migrant group) was drawn from the National Population Registry. Inclusion criteria were: age (18-64 years), country of birth (former Soviet Union or Russia, Iraq or Iran and Somalia), mother tongue (Russian or Finnish for the Russian origin group and Kurdish for the Kurdish origin group), city of residence (Helsinki, Vantaa, Espoo, Turku, Tampere and Vaasa) and minimum one year of residence in Finland. Mother tongue (Kurdish) was used as an additional criteria to identify specifically the Kurdish origin population originating from Iran and Iraq. Similarly, Russian or Finnish language was used to identify the Russian-speaking population originating from the broad geographical region of the former Soviet Union and Ingrian Finns.

The Maamu Study consisted of a face-to-face interview and a health examination, conducted by trained multilingual fieldwork personnel. A brief interview was available for those not able to participate in the full study. Participation rate in at least one part of the study was $70 \%$ for Russian, $51 \%$ for Somali and $63 \%$ for the Kurdish group. The sample of the present study is limited to 464 Russian (46\%), 372 Somali (37\%) and 504 Kurdish (50\%) participants who took part in the health examination and the face-to-face interview (or the brief interview) of the study and thus for whom anthropometric measurement were available.

Reference data for the general population in Finland were obtained from the Health 2011 Survey (Koskinen, Lundqvist and Ristiluoma 2012), conducted by the National Institute for Health and Welfare between 2011 and 2012. Health 2011 Survey followed a similar standardized protocol as the Maamu Study. The reference group of the present study ( $\mathrm{n}=953$ ) included participants of the same age range and living in the same cities as in the Maamu study. Both the Maamu Study and the Health 2011 Survey were ap- 
proved by the Coordinating Ethical Committee of the Helsinki and Uusimaa Hospital Region, Finland. Participants gave written informed consent.

\section{Measures}

Standardised measurements of weight and height were taken during the health examination. For the measurements, participants were asked to remove their outer clothing, including shoes. Height was measured standing upright and looking straight ahead with the Seca 213 stand-alone stadiometer. Weigh was measured wearing light clothing with the Seca 709 beam scale. In the Health 2011 survey, weight was measured as part of the bioimpedance body composition analysis (Seca 514). Weight was not measured if the participant was over 20 weeks pregnant.

Body mass index (BMI) was calculated based on measured weight and height $\mathrm{kg} / \mathrm{m} 2$ and classified according to WHO recommendations: underweight $\left(\leq 18.5 \mathrm{~kg} / \mathrm{m}^{2}\right)$, normal weight $\left(18.5-24.9 \mathrm{~kg} / \mathrm{m}^{2}\right)$, overweight $\left(25.0-29.9 \mathrm{~kg} / \mathrm{m}^{2}\right)$, obesity $(30.0-34.9$ $\left.\mathrm{kg} / \mathrm{m}^{2}\right)$, severe obesity $\left(35.0-39.9 \mathrm{~kg} / \mathrm{m}^{2}\right)$ and morbid obesity $\left(\geq 40 \mathrm{~kg} / \mathrm{m}^{2}\right)$. In this study, also a dichotomized variable of BMI for overweight and obesity was used, with the cut-off of $\geq 25 \mathrm{~kg} / \mathrm{m}^{2}$. Taylor et al. (2006) have studied the relationship between selfreported and clinical measurements for height and weight in adults and concluded that prevalence estimates obtained by self-reports are likely to be underestimations for weight and overestimations for height. This seemed to be true also in the sample of the present study. Therefore, BMI was calculated only based on measured data even though self-report data was also gathered in the face-to-face interview.

The interview included socio-demographic and health-related questions, including education, occupation, years of stay in Finland, physical activity, and parity. These variables were selected based on literature demonstrating their associations with overweight and obesity used to examine factors associated with overweight and obesity among the studied groups.

\section{Statistical analysis}

Analyses were conducted using SAS 9.3/SUDAAN 11.0.1 software. All analyses were stratified by sex and conducted using inverse probability weights (IPWs). IPWs were calculated to reduce bias due to non-response. Age-adjusted prevalence rates of overweight and obesity in the studied population groups were calculated by sex using predictive margins. The association between overweight and obesity with background factors were calculated using logistic regression analysis. Statistical significance was calculated using the Satterthwaite F-statistic. The association between population group and overweight and obesity were examined adjusting for age and for socio-demographic variables considered to be confounding variables. P-value of $<0.05$ was considered statistically significant. Results are presented as age-adjusted prevalence rates or odds ratios (OR) with 95\% confidence intervals (CI). 


\section{Results}

Descriptive characteristics of the study groups are presented in Table 1. Nearly half of the Somali origin women (40\%) reported no formal education. A large proportion of persons of migrant origin were unemployed (24-30\%). Most of the study participants had lived in Finland for more than five years. Only a small proportion of men and women of Somali origin reported consuming fresh fruits and vegetables daily $(0.2-$ $2 \%$ ). As many as $65 \%$ of the Somali origin women and $41 \%$ of the Kurdish origin women had given birth three times or more, whereas the respective prevalence was $12 \%$ for women belonging to the general Finnish population and $8 \%$ for women of Russian origin. More than half (54\%) of women belonging to the general Finnish population had never given birth.

Table1. Age-adjusted characteristics of the study groups (\%)1.

\begin{tabular}{|c|c|c|c|c|c|c|c|c|}
\hline & \multicolumn{4}{|c|}{ Men } & \multicolumn{4}{|c|}{ Women } \\
\hline & Russian & Somali & Kurdish & $\begin{array}{l}\text { General } \\
\text { population }\end{array}$ & Russian & Somali & Kurdish & $\begin{array}{l}\text { General } \\
\text { population }\end{array}$ \\
\hline & $\mathrm{N}=168$ & $\mathrm{~N}=155$ & $\mathrm{~N}=277$ & $\mathrm{~N}=923$ & $\mathrm{~N}=300$ & $\mathrm{~N}=222$ & $\mathrm{~N}=238$ & $\mathrm{~N}=1163$ \\
\hline $\mathbf{A g e}^{1}$ & & & & & & & & \\
\hline $18-29$ years & 35.0 & 43.5 & 37.2 & 25.8 & 26.7 & 36.6 & 30.6 & 35.7 \\
\hline $30-44$ years & 34.7 & 38.9 & 41.1 & 31.9 & 28.9 & 41.1 & 47.8 & 28.8 \\
\hline 45-64 years & 30.2 & 17.6 & 21.6 & 42.3 & 44.5 & 22.4 & 21.6 & 35.5 \\
\hline Education & & & & & & & & \\
\hline None & 0.0 & 13.2 & 7.9 & 0.0 & 0.0 & 40.2 & 20.2 & 0.0 \\
\hline Primary school & 25.0 & 43.2 & 49.7 & 50.3 & 15.9 & 45.2 & 40.3 & 31.4 \\
\hline High school & 74.9 & 43.7 & 42.4 & 49.7 & 84.1 & 14.6 & 39.4 & 68.6 \\
\hline $\begin{array}{l}\text { Employment } \\
\text { status }\end{array}$ & & & & & & & & \\
\hline Employed & 53.7 & 30.6 & 45.3 & 66.5 & 45.5 & 18.0 & 29.6 & 61.9 \\
\hline Student & 17.8 & 25.7 & 17.7 & 19.8 & 19.6 & 22.4 & 25.4 & 22.9 \\
\hline Domestic work & 0.4 & 0.0 & 0.9 & 0.1 & 9.7 & 32.2 & 13.1 & 4.6 \\
\hline Unemployed & 26.6 & 32.9 & 30.1 & 4.5 & 23.5 & 24.3 & 27.1 & 3.4 \\
\hline Pensioner & 0.1 & 10.9 & 6.0 & 9.0 & 1.8 & 3.1 & 4.8 & 7.3 \\
\hline $\begin{array}{l}\text { Time lived } \\
\text { in Finland }\end{array}$ & & & & & & & & \\
\hline$\leq 5$ years & 22.3 & 21.5 & 21.7 & $\mathrm{NA}^{2}$ & 23.2 & 21.1 & 17.0 & $\mathrm{NA}^{2}$ \\
\hline $6-14$ years & 47.2 & 36.9 & 53.0 & & 38.0 & 39.7 & 54.7 & \\
\hline$\geq 15$ years & 30.5 & 41.6 & 25.2 & & 38.8 & 39.2 & 28.0 & \\
\hline $\begin{array}{l}\text { Physical } \\
\text { activity }\end{array}$ & & & & & & & & \\
\hline Low & 27.4 & 19.2 & 36.8 & 23.3 & 33.2 & 18.7 & 40.7 & 25.2 \\
\hline Moderate & 36.0 & 63.0 & 32.1 & 37.6 & 37.8 & 63.1 & 41.1 & 44.7 \\
\hline High & 36.6 & 17.8 & 31.1 & 39.1 & 29.1 & 18.3 & 18.2 & 30.0 \\
\hline $\begin{array}{l}\text { Vegetables or } \\
\text { fruits in diet } \\
\text { (days per week) }\end{array}$ & & & & & & & & \\
\hline$<1$ day & 3.0 & 3.0 & 5.6 & 1.6 & 3.4 & 16.6 & 4.6 & 1.6 \\
\hline 1-2 days & 16.0 & 92.2 & 27.4 & 11.4 & 10.6 & 78.8 & 21.1 & 10.3 \\
\hline $3-5$ days & 25.0 & 4.6 & 27.7 & 27.3 & 24.4 & 2.5 & 22.18 & 26.6 \\
\hline 6-7 days & 56.0 & 0.2 & 39.9 & 59.7 & 61.5 & 2.0 & 51.5 & 61.4 \\
\hline Parity & & & & & & & & \\
\hline 0 births & & & & & 33.2 & 16.5 & 22.5 & 53.5 \\
\hline $1-2$ births & & & & & 58.8 & 18.1 & 36.9 & 34.5 \\
\hline$\geq 3$ births & & & & & 8.0 & 65.4 & 40.6 & 12.0 \\
\hline
\end{tabular}



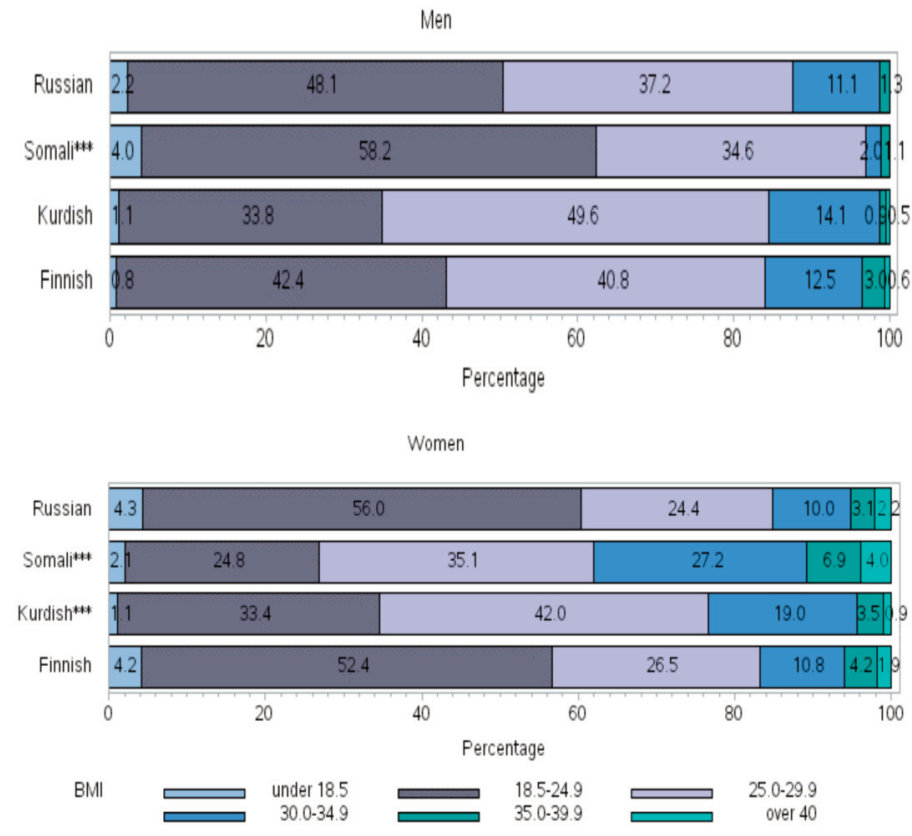

Figure 1. BMI distributions by population groups and gender (\%)1.

\footnotetext{
$1 \quad$ Age-adjusted and weighted prevalences

*** Statistically significant difference in BMI distribution between the study population and the general population
}

BMI distributions among the study groups are presented in Figure 1. Adjusted odds ratios for overweight and obesity by migrant group and sex in comparison with the general Finnish population are presented in Table 2. Age-adjusted prevalence of overweight and obesity was higher among Somali (73.2\%; OR 4.31; 95\% CI 2.57-7.23) and Kurdish origin women $(65.4 \%$; OR $2.86 ; 95 \%$ CI $1.77-4.62)$ compared with women in the general Finnish population (43.4\%). In contrast, Somali origin men $(37.7 \%$; OR 0.41; 95\% CI 0.24-0.72) had a lower prevalence of overweight and obesity compared with men in the general Finnish population (56.9\%). Prevalence of overweight and obesity did not differ significantly between Russian and Kurdish origin men and Russian origin women compared with the general Finnish population. Differences in the prevalence of overweight and obesity among Somali and Kurdish origin women remained statistically significant following additional adjustment for socio-demographic factors (education, employment status; Model 2) and lifestyle factors (physical activity, diet; Models 3-4). Age-adjusted differences remained significant also when adjusted for parity alone (Model 5). Adjustment for age, parity and socio-demographic factors, on the other hand, accounted for the differences in the prevalence of overweight and obesity among Somali (OR 1.45; 95\% CI 0.82-2.54), but not among Kurdish origin women (OR 1.74; 95\% CI 1.11-2.74). 
Table 2. Adjusted odds ratios for overweight and obesity by migrant group and sex in comparison with the general Finnish population.

\begin{tabular}{|l|l|l|l|c|}
\hline & Russian & Somali & Kurdish & $\begin{array}{l}\text { General } \\
\text { population }\end{array}$ \\
\cline { 2 - 5 } & OR (95\% CI) & OR (95\% CI) & OR (95\% CI) & OR (95\% CI) \\
\hline MEN & $0.75(0.45-1.26)$ & $0.41(0.24-0.72)$ & $1.37(0.86-2.20)$ & 1.00 \\
\hline Model 1: Age & $0.67(0.42-1.07)$ & $0.41(0.24-0.71)$ & $1.33(0.87-2.05)$ & 1.00 \\
\hline $\begin{array}{l}\text { Model 2: Age, education, } \\
\text { employment status }\end{array}$ & $0.66(0.42-1.06)$ & $0.40(0.23-0.70)$ & $1.28(0.83-1.98)$ & 1.00 \\
\hline $\begin{array}{l}\text { Model 3: Age, education, } \\
\text { employment status, } \\
\text { physical activity }\end{array}$ & $0.67(0.42-1.06)$ & $0.39(0.22-0.70)$ & $1.37(0.89-2.10)$ & 1.00 \\
\hline $\begin{array}{l}\text { Model 4: Age, education, } \\
\text { employment status, diet }\end{array}$ & $0.90(0.60-1.34)$ & $4.31(2.57-7.23)$ & $2.86(1.77-4.62)$ & 1.00 \\
\hline WOMEN & $0.85(0.59-1.22)$ & $2.88(1.77-4.69)$ & $2.20(1.45-3.35)$ & 1.00 \\
\hline Model 1: Age & & & $1.96(1.29-2.96)$ & 1.00 \\
\hline $\begin{array}{l}\text { Model 2: Age, education, } \\
\text { employment status }\end{array}$ & $0.82(0.57-1.18)$ & $3.21(1.90-5.42)$ & 1.00 \\
\hline $\begin{array}{l}\text { Model 3: Age, education, } \\
\text { employment status, } \\
\text { physical activity }\end{array}$ & $0.82(0.57-1.19)$ & $2.11(1.24-3.57)$ & $2.16(1.40-3.34)$ & 1.00 \\
\hline $\begin{array}{l}\text { Model 4: Age, education, } \\
\text { employment status, diet }\end{array}$ & $0.86(0.57-1.29)$ & $1.90(1.06-3.40)$ & $2.10(1.27-3.47)$ & 1.00 \\
\hline Model 5: Age and parity & $0.83(0.57-1.19)$ & $1.45(0.82-2.54)$ & $1.74(1.11-2.74)$ & \\
\hline $\begin{array}{l}\text { Model 6: Age, education, } \\
\text { employment status, parity }\end{array}$ & 0.900 \\
\hline
\end{tabular}

$\mathrm{OR}=\quad$ Odds ratio

$95 \% \mathrm{CI}=95 \%$ confidence interval

Tables 3 and 4 present age-adjusted odds ratios for overweight and obesity according to background characteristics within migrant groups in men and women respectively. Prevalence of overweight and obesity increased with age among women in all of the study groups. Among men, older age was associated with overweight and obesity among Russian and Kurdish origin men and the association was borderline statistically significant among men in the general Finnish population. In Somali men, age was not associated with overweight and obesity. Lower education was associated with overweight and obesity in women belonging to the general population, but not in migrant origin women. No association between age and education was found among men. In Kurdish women, unemployment and economic inactivity were associated with overweight and obesity. In contrast, employment was associated with a higher prevalence of overweight and obesity than unemployment among Russian origin men and economical inactivity among Kurdish origin men and men belonging to the general Finnish population. 
Table 3. Age-adjusted odds ratios for overweight and obesity according to background characteristics within migrant groups in men.

\begin{tabular}{|c|c|c|c|c|}
\hline & Russian & Somali & Kurdish & General population \\
\hline & OR $(95 \% \mathrm{CI})$ & OR $(95 \% \mathrm{CI})$ & OR $(95 \% \mathrm{CI})$ & OR $(95 \% \mathrm{CI})$ \\
\hline $\begin{array}{l}\text { Age }^{1} \\
18-39 \text { years } \\
40-64 \text { years }\end{array}$ & $\begin{array}{c}1.00 \\
4.48(2.12-9.48)\end{array}$ & $\begin{array}{c}1.00 \\
1.28(0.59-2.78)\end{array}$ & $\begin{array}{c}1.00 \\
4.03(2.32-6.97)\end{array}$ & $\begin{array}{c}1.00 \\
2.00(0.99-4.04)\end{array}$ \\
\hline $\begin{array}{l}\text { Education } \\
\text { Less than primary school } \\
\text { Primary school } \\
\text { High school }\end{array}$ & $\begin{array}{c}\text { NA2 } \\
0.70(0.28-1.76) \\
1.00\end{array}$ & $\begin{array}{c}1.54(0.54-4.38) \\
0.68(0.25-1.83) \\
1.00\end{array}$ & $\begin{array}{c}0.63(0.23-1.73) \\
1.04(0.60-1.79) \\
1.00\end{array}$ & $\begin{array}{c}\mathrm{NA}^{2} \\
1.49(0.86-2.59) \\
1.00\end{array}$ \\
\hline $\begin{array}{l}\text { Employment status } \\
\text { Economically inactive }^{3} \\
\text { Unemployed } \\
\text { Employed }\end{array}$ & $\begin{array}{c}0.35(0.10-1.16) \\
0.33(0.13-0.81) \\
1.00\end{array}$ & $\begin{array}{c}0.42(0.12-1.40) \\
1.82(0.60-5.45) \\
1.00\end{array}$ & $\begin{array}{c}0.50(0.27-0.91) \\
1.24(0.65-2.35) \\
1.00\end{array}$ & $\begin{array}{c}0.32(0.13-0.78) \\
0.82(0.28-2.42) \\
1.00\end{array}$ \\
\hline $\begin{array}{l}\text { Time lived in Finland } \\
\leq 5 \text { years } \\
6-14 \text { years } \\
\geq 15 \text { years }\end{array}$ & $\begin{array}{c}1.93(0.68-5.49) \\
1.68(0.65-4.32) \\
1.00\end{array}$ & $\begin{array}{c}1.32(0.41-4.21) \\
3.00(1.09-8.20) \\
1.00\end{array}$ & $\begin{array}{c}1.00(0.47-2.10) \\
0.88(0.48-1.63) \\
1.00\end{array}$ & $\mathrm{NA}^{4}$ \\
\hline $\begin{array}{l}\text { Physical activity } \\
\text { Low } \\
\text { Moderate } \\
\text { High }\end{array}$ & $\begin{array}{c}2.53(0.95-6.75) \\
2.17(0.86-5.49) \\
1.00\end{array}$ & $\begin{array}{c}0.43(0.13-1.39) \\
0.80(0.30-2.11) \\
1.00\end{array}$ & $\begin{array}{c}1.04(0.56-1.95) \\
0.94(0.47-1.86) \\
1.00\end{array}$ & $\begin{array}{c}0.95(0.37-2.44) \\
1.04(0.42-2.56) \\
1.00\end{array}$ \\
\hline $\begin{array}{l}\text { Vegetables or fruits in diet } \\
\text { Less than } 6 \text { days a week } \\
6-7 \text { days a week }\end{array}$ & $\begin{array}{c}0.68(0.31-1.49) \\
1.00\end{array}$ & $\begin{array}{l}\mathrm{NA}^{2} \\
1.00\end{array}$ & $\begin{array}{c}0.64(0.37-1.08) \\
1.00\end{array}$ & $\begin{array}{c}2.71(1.24-5.93) \\
1.00\end{array}$ \\
\hline
\end{tabular}

$\mathrm{OR}=\quad$ Odds ratio

95\% CI $=95 \%$ confidence interval

$1 \quad$ Unadjusted

$\mathrm{NA}^{2}=$ Too few observations for statistical analysis

3 Economically inactive includes housekeepers, students and pensioners

$\mathrm{NA}^{4}=$ Data not available for Finnish reference group

Somali origin men who had lived in Finland for 6-14 years were more likely to be overweight or obese than those who had lived in Finland for longer. Low levels of physical activity were associated with overweight and obesity among Russian origin women and women belonging to the general Finnish population. No statistically significant associations between physical activity levels and overweight and obesity were found among men. Eating fresh fruits and vegetables less than daily was associated with 
Table 4. Age-adjusted odds ratios for overweight and obesity according to background characteristics within migrant groups in women.

\begin{tabular}{|c|c|c|c|c|}
\hline & Russian & Somali & Kurdish & General population \\
\hline & OR $(95 \% \mathrm{CI})$ & OR $(95 \% \mathrm{CI})$ & OR $(95 \% \mathrm{CI})$ & OR $(95 \% \mathrm{CI})$ \\
\hline $\begin{array}{l}\text { Age }^{1} \\
18-39 \text { years } \\
40-64 \text { years }\end{array}$ & $\begin{array}{c}1.00 \\
6.48(3.71-11.29)\end{array}$ & $\begin{array}{c}1.00 \\
14.31(5.47-37.43)\end{array}$ & $\begin{array}{c}1.00 \\
3.69(2.08-6.54)\end{array}$ & $\begin{array}{c}1.00 \\
4.05(2.14-7.65)\end{array}$ \\
\hline $\begin{array}{l}\text { Education } \\
\text { Less than primary school } \\
\text { Primary school } \\
\text { High school }\end{array}$ & $\begin{array}{c}\mathrm{NA}^{2} \\
1.57(0.75-3.29) \\
1.00\end{array}$ & $\begin{array}{c}0.54(0.18-1.65) \\
0.85(0.32-2.26) \\
1.00\end{array}$ & $\begin{array}{c}2.33(0.94-5.77) \\
0.83(0.46-1.49) \\
1.00\end{array}$ & $\begin{array}{c}\mathrm{NA}^{2} \\
1.90(1.22-2.94) \\
1.00\end{array}$ \\
\hline $\begin{array}{l}\text { Employment status } \\
\text { Economically inactive } \\
\text { Unemployed } \\
\text { Employed }\end{array}$ & $\begin{array}{c}1.16(0.56-2.42) \\
1.15(0.59-2.23) \\
1.00\end{array}$ & $\begin{array}{c}1.18(0.41-3.40) \\
3.67(0.87-15.51) \\
1.00\end{array}$ & $\begin{array}{c}2.75(1.42-5.33) \\
3.81(1.62-8.97) \\
1.00\end{array}$ & $\begin{array}{c}1.20(0.50-2.90) \\
0.86(0.29-2.52) \\
1.00\end{array}$ \\
\hline $\begin{array}{l}\text { Time lived in Finland } \\
\leq 5 \text { years } \\
6-14 \text { years } \\
\geq 15 \text { years }\end{array}$ & $\begin{array}{c}0.87(0.38-1.98) \\
1.03(0.56-1.91) \\
1.00\end{array}$ & $\begin{array}{c}0.78(0.24-2.46) \\
1.16(0.44-3.08) \\
1.00\end{array}$ & $\begin{array}{c}0.94(0.41-2.18) \\
0.88(0.45-1.69) \\
1.00\end{array}$ & $\mathrm{NA}^{4}$ \\
\hline $\begin{array}{l}\text { Physical activity } \\
\text { Low } \\
\text { Moderate } \\
\text { High }\end{array}$ & $\begin{array}{c}2.49(1.17-5.30) \\
1.30(0.63-2.72) \\
1.00\end{array}$ & $\begin{array}{c}0.83(0.20-3.40) \\
1.74(0.51-5.91) \\
1.00\end{array}$ & $\begin{array}{c}1.89(0.92-3.88) \\
1.78(0.88-3.61) \\
1.00\end{array}$ & $\begin{array}{c}2.79(1.12-6.96) \\
1.81(0.81-4.03) \\
1.00\end{array}$ \\
\hline $\begin{array}{l}\text { Vegetables or fruits in diet } \\
\text { Less than } 6 \text { days a week } \\
6-7 \text { days a week }\end{array}$ & $\begin{array}{c}1.53(0.82-2.87) \\
1.00\end{array}$ & $\begin{array}{l}\mathrm{NA}^{2} \\
1.00\end{array}$ & $\begin{array}{c}1.09(0.62-1.93) \\
1.00\end{array}$ & $\begin{array}{c}1.61(0.79-3.29) \\
1.00\end{array}$ \\
\hline $\begin{array}{l}\text { Parity } \\
0 \text { births } \\
1-2 \text { births } \\
\geq 3 \text { births }\end{array}$ & $\begin{array}{c}1.00 \\
1.05(0.41-2.67) \\
2.07(0.67-6.40)\end{array}$ & $\begin{array}{c}1.00 \\
1.80(0.55-5.87) \\
2.44(0.82-7.29)\end{array}$ & $\begin{array}{c}1.00 \\
2.92(1.29-6.61) \\
4.95(1.95-12.5)\end{array}$ & $\begin{array}{c}1.00 \\
0.93(0.56-1.54) \\
0.93(0.48-1.81)\end{array}$ \\
\hline
\end{tabular}

$\mathrm{OR}=$ Odds ratio

$95 \% \mathrm{CI}=95 \%$ confidence interval

$1 \quad$ Unadjusted

$\mathrm{NA}^{2}=$ Too few observations for statistical analysis

$3 \quad$ Economically inactive includes housekeepers, students and pensioners

$\mathrm{NA}^{4}=$ Data not available for Finnish reference group

higher prevalence of overweight and obesity among men in the general Finnish population only. Statistically significant associations between parity and overweight and obesity were found among Kurdish origin women only. 


\section{Discussion}

The aim of the present study was to assess the prevalence of overweight and obesity among persons of Russian, Somali and Kurdish origin in Finland in comparison to the general Finnish population and to determine which socio-demographic and lifestyle factors are associated with overweight and obesity in the studied groups. Somali origin women were four times, whereas women of Kurdish origin were almost three times more likely to be overweight or obese than women in the general Finnish population. As many as $73 \%$ of the Somali origin women and $65 \%$ of the Kurdish origin women were overweight or obese. These findings are in line with previous studies. A Norwegian study found that $66 \%$ (Daryani et al. 2005) and a New Zealander study found that $71 \%$ (Guerin, Elmi and Corrigan 2007) of Somali origin women had a BMI $\geq 25 \mathrm{~kg} / \mathrm{m}^{2}$. No previous studies on the prevalence of overweight and obesity specifically among Kurdish origin populations were identified. However, prevalence of overweight and obesity have been reported to be high also in women of Turkish and Iranian origin (Kumar et al. 2009). Several other studies have also reported a high prevalence in general and abdominal obesity among Somali origin women (Gele et al. 2016; Skogberg et al. 2016).

Differences in the prevalence of overweight and obesity by sex observed in the present study are also consistent with findings of previous research. A Norwegian study found a significantly higher prevalence of overweight and obesity among women originating from Turkey and Iran compared with men from the same groups (Kumar et al. 2009). Similar findings were observed in Sweden (Daryani et al. 2005). In line with these, Gele and Mbalilaki (2013) found that Somali origin women living in Oslo had a significantly higher prevalence of overweight and obesity than men. It is possible that to an extent, cultural factors, social norms and lack of knowledge on health-promoting behaviour may contribute to the observed sex differences in overweight and obesity among Somali and Kurdish origin women in the present study. It has been, for example, suggested that persons of Somali origin may consider overweight and obesity particularly among women as a sign of prosperity, success and good health rather than disease (Renzaho 2004; Schwartz 2008). Women belonging to these migrant groups may also experience more barriers to taking part in physical activity than men due to cultural and social reasons.

Cultural dimensions of barriers to physical activity among Somali origin women in Finland have been explored in ethnographic studies by Tiilikainen (2003) and Isotalo (2015). According to these studies, cultural practices and understandings, including social norms, have a strong influence on physical activity levels among Somali origin women. Traditionally among Somali women, physical activity is rarely an activity taken up for the sole purpose of exercise. Rather, light to moderate levels of physical activity, such as walking, is more likely to occur when taking care of various chores outside of the home. Cultural and social norms influence perceptions of when and for what reasons it is acceptable for a Somali woman to carry out activities outside of the home (Tiilikainen 2003; Isotalo 2015). 
Dietary factors, measured with consumption of fresh fruit and vegetables did not account for the high prevalence of overweight and obesity among Somali and Kurdish origin women. Consumption of fresh fruits and vegetables was overall very low among persons of Somali origin. This may be related to culturally-tied preferences and customs. Instead of consuming fresh fruits and vegetables, persons of Somali origin may be more likely to consume vegetables cooked in stews. There are geographical variations in Somalia in availability of fresh fruits. Furthermore, the types of fruits available in Somalia and in Finland differ. Restricted availability of similar fruits and vegetables as in Somalia may also influence consumption of fresh fruits and vegetables. Furthermore, it has been previously suggested that in Somali culture, fruits and vegetables are associated with poverty whereas red meat is associated with affluence (McEwen, Straus and Ussher 2008) More comprehensive measures of dietary intake are needed to examine the association between dietary factors and observed high prevalence of overweight and obesity. Food insecurity has also been previously reported to be associated with overweight and obesity among Somali origin women in United States (Dharod, Croom and Sady 2013). Food insecurity has been linked to inadequate diet and people who are food insecure also have a lower intake of fruit and vegetables (Grutzmacher and Gross 2011; Kendall, Olson and Frongillo 1996).

Adjustment for age, parity and socio-demographic factors accounted for the differences in the prevalence of overweight and obesity among women of Somali origin compared with women in the general Finnish population. Of socio-demographic factors, education is closely related to health and wellbeing (Pentala-Nikulainen et al. 2018). For example, it is associated with ability to access and process information on lifestyles advantageous for health (Hirvonen et al. 2015). Education is also closely related to employment opportunities. Women of particularly Somali, but also Kurdish origin had a high proportion of those who had low level of education and low employment rates. Therefore, women belonging to these groups are likely to benefit from tailored interventions aiming at improving health education. Findings of the present study also suggest that women of Somali origin may need information and support on managing weight after giving birth as parity combined with socio-demographic factors accounted for the observed high prevalence of overweight and obesity in this group.

Prevalence of overweight and obesity remained higher among Kurdish origin women compared with women in the general Finnish population even after adjustment for a variety of socio-demographic and lifestyle factors. Nonetheless, parity was associated with increased odds for overweight and obesity among Kurdish women. Therefore, it is likely that also Kurdish origin women would benefit from interventions supporting weight control after giving birth. Future studies should focus on identifying additional risk factors for the observed high prevalence of overweight and obesity among Somali and Kurdish origin women, including the influence of refugee background, mental health status and discrimination. Approximately three quarters of Somali and Kurdish origin participants in the present study had a refugee background whereas persons of Russian origin, in general, had migrated to Finland voluntarily. Prevalence 
of obesity has been found to be associated with poorer mental health and discrimination (Dallman et al. 2003; Thompson 2012). Particularly persons of Kurdish origin have been reported to have a high prevalence of mental health symptoms in Finland (Rask et al. 2017). Experiences of discrimination among persons of migrant origin in Finland are also common (Castaneda et al. 2015; Rask et al. 2018). Long-term effects of discrimination on the health and wellbeing, and particularly its association with overweight and obesity, is an important topic for future research.

\section{Strengths and limitations}

The main strengths of the present study are study design, randomized sampling and the use of standardised objective health examination measures. An additional strength is the relatively high participation rate compared to many other studies among persons of migrant origin. A further strength is that analyses were conducted by migrant group and by sex, as well as inclusion of the general Finnish population as the reference group. Information on the prevalence of overweight and obesity specifically among persons of Kurdish origin as well as factors associated with these has been previously unavailable.

However, some limitations also need to be addressed. This study focuses on three migrant origin populations and findings cannot be generalised to all persons of migrant origin in Finland. The cross-sectional design of the study does not allow for examining causality. Use of BMI as a measure of obesity can also be seen as somewhat of a limitation as there is critique concerning how well BMI takes into account ethnic differences in body composition and hence depicts the actual prevalence of overweight and obesity among ethnically diverse populations (Skogberg 2018). Further studies should therefore include also other measures of overweight and obesity, such as abdominal obesity and waist-to-height ratio, as well as on identifying appropriate BMI cut-offs for ethnically diverse population groups.

\section{Conclusion}

The key findings of the present study are that Somali and Kurdish origin women have a significantly higher prevalence of overweight and obesity than women in the general Finnish population. Differences in factors associated with overweight and obesity among the studied population groups were also observed. Overall, findings of the present study indicate a particular need for interventions aiming at reducing obesity among women of Somali and Kurdish origin. Addressing cultural and social perceptions of overweight and obesity and behaviours associated with these through providing easily understandable and accessible information on health is crucial when designing health promotion interventions for these population groups. Addressing the issue of overweight and obesity among persons of migrant origin, as well as identifying additional risk factors related to these is especially needed with increasing population diversity in Finland. 


\section{References}

Antecol H, Bedard K. Unhealthy assimilation: why do immigrants converge to American health status levels? Demography 2006;43(2):337-360.

Caballero B. The global epidemic of obesity: an overview. Epidemiol Rev 2007;29:1-5.

Castaneda AE, Rask S, Koponen P, Suvisaari J, Koskinen S, Härkänen T, et al. The Association between Discrimination and Psychological and Social Well-being A Population-based Study of Russian, Somali and Kurdish Migrants in Finland. Psychology \& Developing Societies 2015;27(2):270-292.

Castaneda AE, Rask S, Härkänen T, Juntunen T, Skogberg N, Mölsä M, Tolonen H, Koskinen S, Koponen P. Enhancing Survey Participation among Foreign-Born Populations: Experiences from the Finnish Migrant Health and Wellbeing Study (Maamu). Finnish Yearbook of Population Research, submitted for publication.

Dallman MF, Pecoraro N, Akana SF, La Fleur SE, Gomez F, Houshyar H, et al. Chronic stress and obesity: a new view of "comfort food". Proc Natl Acad Sci U S A 2003 Sep 30;100(20):1169611701.

Daryani A, Berglund L, Andersson Å, Kocturk T, Becker W, Vessby B. Risk factors for coronary heart disease among immigrant women from Iran and Turkey, compared to women of Swedish ethnicity. Ethn Dis 2005;15(2):213-220.

Davis EM, Zyzanski SJ, Olson CM, Stange KC, Horwitz RI. Racial, ethnic, and socioeconomic differences in the incidence of obesity related to childbirth. Am J Public Health 2009;99(2):294-299.

Delavari M, Sonderlund AL, Swinburn B, Mellor D, Renzaho A. Acculturation and obesity among migrant populations in high income countries--a systematic review. BMC Public Health 2013 May 10;13:458-2458-13-458.

Dharod JM, Croom JE, Sady CG. Food insecurity: its relationship to dietary intake and body weight among Somali refugee women in the United States. Journal of nutrition education and behavior 2013;45(1):47-53.

Everson SA, Maty SC, Lynch JW, Kaplan GA. Epidemiologic evidence for the relation between socioeconomic status and depression, obesity, and diabetes. J Psychosom Res 2002;53(4):891895.

Flegal KM, Carroll MD, Kit BK, Ogden CL. Prevalence of obesity and trends in the distribution of body mass index among US adults, 1999-2010. JAMA 2012;307(5):491-497.

Franzen L, Smith C. Acculturation and environmental change impacts dietary habits among adult Hmong. Appetite 2009 2;52(1):173-183.

Gele AA, Mbalilaki AJ. Overweight and obesity among African immigrants in Oslo. BMC Res Notes 2013 Mar 26;6:119-0500-6-119.

Gele AA, Pettersen KS, Kumar B, Torheim LE. Diabetes Risk by Length of Residence among Somali Women in Oslo Area. Journal of Diabetes Research 2016;2016.

Groves T. Pandemic obesity in Europe. BMJ 2006 Nov 25;333(7578):1081.

Grutzmacher S, Gross S. Household food security and fruit and vegetable intake among low-income fourth-graders. Journal of nutrition education and behavior 2011;43(6):455-463.

Guerin PB, Elmi FH, Corrigan C. Body composition and cardiorespiratory fitness among refugee Somali women living in New Zealand. Journal of Immigrant and Minority Health 2007;9(3):191-196.

Hirvonen N, Ek S, Niemelä R, Korpelainen R, Huotari M (2015). Sociodemographic characteristics associated with the everyday health information literacy of young men. Information Research: An International Electronic Journal, 20. 
Isotalo A. Mistä on hyvät tytöt tehty? Somalitytöt ja maineen merkitykset. University of Turku, 2015. Available from: http://urn.fi/URN:ISBN:978-951-29-6169-6. Accessed 25.6.2019.

Kendall A, Olson CM, Frongillo EA. Relationship of hunger and food insecurity to food availability and consumption. J Am Diet Assoc 1996;96(10):1019-1024.

Kim S, Stein A, Martorell R. Country development and the association between parity and overweight. Int J Obes 2007;31(5):805-812.

Koskinen S, Lundqvist A, Ristiluoma N. Terveys, toimintakyky ja hyvinvointi Suomessa 2011. Raportti: 2012_0682012.

Kumar BN, Selmer R, Lindman AS, Tverdal A, Falster K, Meyer HE. Ethnic differences in SCORE cardiovascular risk in Oslo, Norway. Eur J Cardiovasc Prev Rehabil 2009 Apr;16(2):229-234.

Lahti-Koski M, Vartiainen E, Männistö S, Pietinen P. Age, education and occupation as determinants of trends in body mass index in Finland from 1982 to 1997. Int J Obes 2000;24(12):16691676.

McEwen A, Straus L, Ussher M. Physical inactivity among a UK Somali population. J Public Health (Oxf) 2008 Mar;30(1):110.

Ministry of the Interior. Maahanmuuton tulevaisuus 2020 -strategia. 2016; Available at: http://www.intermin.fi/maahanmuutto2020. Accessed 10.5, 2016.

Männistö S, Laatikainen T, Harald K, Borodulin K, Jousilahti P, Kanerva N, et al. Työikäisten ylipainon ja lihavuuden kasvu näyttää hidastuneen: kansallisen FINRISKI-terveystutkimuksen tuloksia. 2015.

Oza-Frank R, Cunningham SA. The weight of US residence among immigrants: a systematic review. Obesity Reviews 2010;11(4):271-280.

Pentala-Nikulainen O, Koskela T, Parikka S, Kilpeläinen H, Koskenniemi T, Aalto A, Muuri A, Koskinen S, Lounamaa A (2018). Kansallisen terveys-, hyvinvointi ja palvelututkimus FinSoten perustulokset 2017-2018. Available at: http://www.terveytemme.fi/finsote/. Accessed 25.6.2019.

Rask S, Suvisaari J, Koskinen S, Koponen P, Molsa M, Lehtisalo R, et al. The ethnic gap in mental health: A population-based study of Russian, Somali and Kurdish origin migrants in Finland. Scand J Public Health 2016 May;44(3):281-290.

Rask S, Elo I. T., Koskinen S, Lilja E, Koponen P, Castaneda A. E. The association between discrimination and health: findings on Russian, Somali and Kurdish origin populations in Finland. Eur J Public Health. 2018 Oct 1;28(5):898-903.

Renzaho AM. Fat, rich and beautiful: changing socio-cultural paradigms associated with obesity risk, nutritional status and refugee children from sub-Saharan Africa. Health Place 2004;10(1):105-113.

Ro A, Bostean G. Duration of U.S. stay and body mass index among Latino and Asian immigrants: A test of theoretical pathways. Soc Sci Med 2015 11;144:39-47.

Salama E, Niemelä S, Suvisaari J, Laatikainen T, Koponen P, Castaneda AE. The prevalence of substance use among Russian, Somali and Kurdish migrants in Finland: a population-based study. BMC Public Health 2018;18:651.

Schwartz K. Hyperlipidemia: Diet, Education, and Health Promotion for the Somali Refugee Population. 2008. EthnoMed website:

http://ethnomed.org/ethnomed/clin_topics/hyperlipidemia_somali.htm.

Singh GK, Siahpush M, Hiatt RA, Timsina LR. Dramatic increases in obesity and overweight prevalence and body mass index among ethnic-immigrant and social class groups in the United States, 1976-2008. J Community Health 2011;36(1):94-110. 
Skogberg N, Laatikainen T, Koskinen S, Vartiainen E, Jula A, Leiviska J, et al. Cardiovascular risk factors among Russian, Somali and Kurdish migrants in comparison with the general Finnish population. Eur J Public Health 2016 Aug;26(4):667-673.

Skogberg N, Laatikainen T, Lundqvist A, Lilja E, Härkänen T, Koponen P. 2018. Which anthropometric measures best indicate type 2 diabetes among Russian, Somali and Kurdish origin migrants in Finland? BMJ Open; May 17;8(5):e019166.

Sussner KM, Lindsay AC, Greaney ML, Peterson KE. The influence of immigrant status and acculturation on the development of overweight in Latino families: a qualitative study. Journal of Immigrant and Minority Health 2008;10(6):497-505.

Taylor AW, Grande ED, Gill TK, Chittleborough CR, Wilson DH, Adams RJ, et al. How valid are self-reported height and weight? A comparison between CATI self-report and clinic measurements using a large cohort study. Aust N Z J Public Health 2006;30(3):238-246.

Thompson Jr D. The Link Between Stress and Obesity. Retrieved August 2012;12:3013.

Tiilikainen M. Arjen islam: Somalinaisten elämää Suomessa. Vastapaino, 2003.

Toselli S, Gualdi-Russo E, Boulos DN, Anwar WA, Lakhoua C, Jaouadi I, et al. Prevalence of overweight and obesity in adults from North Africa. Eur J Public Health 2014 Aug;24 Suppl 1:31-39.

WHO. Obesity and Overweight. 2015; Available at: http://www.who.int/mediacentre/factsheets/fs311/en/. Accessed 20.1, 2016. 